\title{
ANALYTICAL MODEL OF RANDOM MULTIPLE ACCESS PROTOCOL PREDICTIVE P-PERSISTENT CSMA
}

Dadenkov S. A. - PhD, Associate Professor at the Department of «Automatics and telemechanics», Perm National Research Polytechnic University, Perm, Russia.

\begin{abstract}
Context. New model and quantification method of probable and time characteristics of information-control network with carrier sense random multiple access protocol and predicting network load of predictive $p$-persistent CSMA had been created. The object of the research was the process of information exchange in Fieldbus-networks LonWorks, BacNet with the analyzed protocol.

Objective. The aim of the research is to increase the accuracy of quantitative estimates of the characteristics of time and delivery reliability of information messages in the network with the analyzed protocol.

Method. The method of probability theory has been used there to solve the problem of creating a new correct model. The analysis of the functioning principles of the predictive $p$-persistent CSMA protocol is performed and the parameters influencing its work are set (on the example of the LonTalk stack). A graph of states and transitions of the protocol model describing the principles of transmission of information messages over a network with a software communication medium, considering the allocated significant network and protocol parameters. A method for calculating the graph is offered and new analytical relations are obtained to estimate the main model probabilistic and temporal characteristic: the average delay time of message transmission, the average load of the communication channel, the probability of successful/unsuccessful transmission and data loss in the network.

Results. The developed model and method of quantitative assessment of probabilistic and temporal characteristics of data transmission in a network with multiple access protocol predictive $p$-persistent CSMA. The results are mostly differ from analogs by correct accounting of sporadic and diverse network load by the node delivery services.

Conclusions. The held experiments have confirmed the work capacity of the proposed mathematical support and allow to recommend it for solving the assessment characteristics problems of information exchange in the design of analyzed networks with given probabilistic and temporal characteristics.
\end{abstract}

KEYWORDS: protocol model, random multiple access, probabilistic and temporal characteristics, information transmission, industrial network, sensor network, LonWorks, fieldbus, predictive $p$-persistent CSMA.

$\quad$ ABBREVIATIONS
ACKD is an acknowledged message;
ACK is a message-acknowledgment;
REM is a reminder message;
RES is a message-request;
REQ is a response message;
UACKD is a unacknowledged message;
UACKD_RPT is a unacknowledged-repeated message.

\section{NOMENCLATURE}

$A$ - amount of model states;

$B L$ - predicted channel load (backlog);

$b$ - current predicted load;

$B$ - maximum predicted load;

$C$-nominal bandwidth of the network;

$d$-share of network traffic with a concrete message type;

$e$ - number of attempts of successful transmission;

$k$ - allowed amount of retransmissions;

$m$ - current amount of messages in the network;

$M$ - maximum amount of messages in the network;

$n$ - current amount of nodes in the network;

$N$ - maximum amount of nodes in the network;

$\mathrm{O}$ - number of features characterizing original sample;

$p_{\mathrm{\kappa}}$ - probabilities of collision transmission;

$p_{\mathrm{y}}$ - probabilities of successful transmission;

$p_{\text {ну }}$ - probabilities of an unsuccessful transmission;

$p_{\text {п }}$ - probabilities loss of the original message;

$p_{i}$ - probability of generating by the nodes in network $i$ of messages during the packet cycle;

$P L-$ length of the message (package) in bits; $q$ - the node queue size;

$r$ - amount of channels between the receiver node and the sender;

$S$ - number of instances in the original sample;

$u$ - average value of the network characteristic;

$U-$ vectors of state characteristics of the model of the network;

$W_{\text {base }}$ - basic width of the window access;

$W$ - current width of the window access;

$\mathrm{Z}$ - number of instances in the result sample;

$\lambda$ - the intensity of generation by the node;

$\mu$ - intensity of processing the network messages by the channel;

$\tau$ - duration of the packet cycle;

$\beta_{1}-$ minimum interpackage interval of access;

$\beta_{2}-$ duration of the access slot.

\section{INTRODUCTION}

Carrier sense multiple access protocols are widespread and are used in networks with a shared data transfer environment. Nowadays, random access protocols are successfully used in wired industrial, sensor (Fieldbus) and wireless decentralized self-organizing communication networks (MANET). The advantage of random access over deterministic time division of the transmission medium is the ability of providing less time access delays and data transmission over the network. This is possible due to the organization of information transfer only at the necessary time, and not planned accepted "schedule". It is known that the use of random access is effective when the 
value of bandwidth utilization factor of communication channel is less than 0.5 [1]. In other cases, deterministic access methods are mostly used because of warranty intervals of data delivery and the high predictability of the maximum value of access and transfer delay. There is a large variety of different protocols of a random multiple access with carrier sense, the prevention and avoidance of collisions. In fieldbus networks CSMA/CA protocols (industrial buses $\mathrm{CAN}, \mathrm{KNX} / \mathrm{EIB}$, DeviceNet), 1 CSMA/CD (EtherNet/IP, ModBus/TCP), predictive $p$ persistent CSMA (BacNet, LonWorks) could be applied. The distinctive features of the protocols is to ensure the operational efficiency of the network (time and reliability of transmission) at the different: congestion of the network channels, the quantity of nodes, the frequency/sporadicity of the network load and other parameters. Passed in analyzed networks traffic has "exploded" sporadic character. This actualizes the study and application of protocols self-adapting to the changing level of network channel load, in particular, the protocol with predictive load $p$-persistent CSMA.

The object of the study is the process of a node accessing to communication channel and transmitting a message on a network with a random multiple access protocol and avoiding collisions predictive $p$-persistent CSMA. Designing real-time sensor networks is a complex task. The main task is to provide the given probabilistic and temporal characteristics of information exchange. This requires a high accuracy in quantifying the characteristics of the network.

The subject of study is the ways of quantifying of probabilistic and temporal characteristics, reliability of information transmission in networks with random access. The known methods [2-21] have a low level of detail with significant parameters of the protocol functioning and are characterized by tight limitations.

The purpose of the work is to increase the accuracy of quantitative assessments of the probabilistic and temporal characteristics of information exchange in networks with the protocol of random multiple access predictive $p$ persistent CSMA by correctly accounting previously not analyzed in the aggregate parameters of the protocol.

\section{PROBLEM STATEMENT}

The system is characterized by a set of precedents $<x$, $y>$, where $x=\left\{x^{s}\right\}, x=\left\{x_{j}\right\}, x^{s}=\left\{x_{j}^{s}\right\}, x_{j}=\left\{x_{j}^{s}\right\}, y=\left\{y_{z}^{s}\right\}, s=1$, $2, \ldots, S, j=1,2, \ldots, O, z=1,2, \ldots, Z$. The $x$-states of the system change according to the stochastic law. For a given set of precedents $\langle x, y\rangle$ the problem is to find the average $y_{z}$-characteristics of the system.

Set of precedents has finite dimension and the state of the $\mathrm{x}$-system is returnable and nonzero. In this case, the solution is to use the discrete Markov chains calculation method $[22,23]$ and find the stationary probabilities $\pi^{s}$ of the system states. The average values $y_{z}$ of the system can be obtained by superposition of all output values $y_{z}^{s}$ of the set taking into account stationary probabilities of states $y_{z}=\sum y_{z}^{s} \cdot \pi_{\mathrm{s}}$.

\section{REVIEW OF THE LITERATURE}

Wide application for analysis of different network algorithms random access found classical queueing system with repeated calls (resulting from the loss or lack of response), the priorities studied in the works of authors A. A. Nazarov [4-6], I.I. Homichkov [7, 8], S. N. Stepanov [9], etc. The results of these studies can be used to assess the probabilistic and temporal characteristics of networks mostly with 1-persistent protocol of random multiple access CSMA/CD, used in industrial Ethernet, ModbusTCP, EtherNet/IP, HSE, ProfiNet, InterbusTCP/IP, etc. Analytical and simulation modeling of the CSMA/CA random access Protocol in the EIB $\backslash$ KNX network is performed in [10]. The analysis of CAN bus characteristics with CSMA/NBA access algorithm is devoted to the works [11-14]. Works [17-20] are devoted to the analysis of sensor networks LonWorks, BacNet with the protocol with dynamic level of persistence predictive $\mathrm{p}$ persistent CSMA.

Assessment of the characteristics of the analyzed protocol predictive $p$-persistent CSMA is dedicated to a large number of publications, among which are the main works of the authors Moshe Kam [20], Marek Miśkowicz [18, 19], Peter Buchholz and Jorn Plonnigs [17]. The presented models take into account mostly the protocol features of only the channel and physical layers of the OSI model, and do not take into account the significant features of the functioning of the overlying network and transport layer of the protocol stack. The research in [18$20]$ is conducted in the mode of saturation (full load) of the data channel, in which the main factor affecting the probabilistic and temporal characteristics of the network is the constant number of active nodes (and messages) competing for the transmission channel according to the modified protocol predictive $p$-persistent CSMA. The system research in this mode is caused by simplicity of the decision of the task of the quantitative assessment of transmission characteristics by accepting the account of dynamically changing network and protocol parameters of the model, including the changing over time the number of rival nodes and their messages. Models with this restriction can be used for assessment the upper level of delay, without the messages queue arising on the nodes, but cannot be used to exact assess the characteristics of the network in normal operation. The basis for the construction of these analytical models is the apparatus of discrete Markov chains, and the calculation of the probabilities of transitions between the states of the model and the assessment of the characteristics of the model is performed using the apparatus of probability theory.

In work [20] the simplest model of the functioning of the researched protocol and the way of assessment by the transmission delay through the assessment of the average quantity of time slots to the access node to the channel are offered. The results of the assessment can be attributed to the assessments performed for the information delivery service without acknowledgment, which is due to the principle of changing the predicted load identical to this service. In work [19] the development of the model [20] 
of the protocol operation are offered, taking into account features of the transmission services the transport layer and types of addressing of the network layer of OSI in the transmission of messages of different types. In particular, the account methods in the model of homogeneous delivery services are offered: "without acknowledgment", "with acknowledgment", "request-response", and types of addressing "unicast" and "multicast", taking into account their influence on the protocol parameters of the model, including the predicted load on the transmission channel in the case of a certain type of message. The issues of the principles accounting of information delivery are not sufficiently processed: features of delivery service "the repeated transmission without acknowledgment" and types of the transferred messages-reminders (Reminder), the repeated messages (Repeated simple); the number of simultaneously possible outgoing transactions (restricted by the saturation mode, that is, the node always has only one message for transmission); timers and counters for transmission/reception and other important factors of functioning.

Model [18] is the development [19], in which the proposed method of accounting for the heterogeneity of the information load by services of delivery and the types of addressing that is transmitted via a network channels which improves the correctness of the model and assessment results.

In work [17] made the transition to a more adequate model of the protocol of the access nodes to the network, taking into account the random nature of the load on the data transmission channel, given the exponential distribution. The authors analyze the transmission channel by decomposing it into components - nodes, which are represented by elements of the Queuing system and are sources of information, and the transmission channel is a servicing device. On the basis of the mathematical model and the proposed analytical expression [18], the authors further suggested that the accounting methods used the following protocol features: options detection of a collision, the restriction of the buffer size of the node, different dimensions of information messages. Use in the model [17] of these developments in the mode of saturation of the communication channel indicates an incorrectness of the access algorithm for various services and types of addressing.

Analytical review of publications identified the problem of correctness of existing models and quantitative assessments of their probabilistic and temporal characteristics. The problem is in the low detailing of the models by significant protocol parameters and features of functioning: limitation of node rivalry for the channel at the time of getting of all stipulated in the type of transaction response (confirmative) messages; the limit on the waiting time of the acknowledgment (transmission timers); the limit on the number of repeated attempts of transmissions for different types of messages; dependence of the number of rival nodes in the model on their individual intensities and with considering the type of information messages; heterogeneity of delivery services and types of addressing used in the channels of the network; priorities

(C) Dadenkov S. A, 2019

DOI 10.15588/1607-3274-2019-1-18 of access of rival nodes for the channel, etc. This determines the importance of the range of set and solved tasks of the development and analysis of a new correct analytical model and methods of quantitative assessment of probabilistic and temporal characteristics of the network with the protocol of random multiple access predictive $p$ persistent CSMA.

\section{MATERIALS AND METHODS}

The predictive $p$-persistent CSMA random access protocol is a protocol with a variable (pseudo - constant) level of persistence p-nodes of network for channel access. The level of persistence of nodes during transmission varies in the range [0.0625..0.000976] with changing predicted channel load. The adjusting of persistence allows to reduce the chance of collision when the load on the network channel increases and reduce the access time when the channel load decreases.

Data transmission in the network with the protocol is performed in synchronous packet cycles (Fig. 1) $[2,3]$ containing: 1) minimum inter-packet time interval $\beta_{1}$ of establishing the lack of activity in the communication channel; 2) priority interval equal to the number of priority access time slots, with the duration of each $\beta_{2} ; 3$ ) random access interval $T$, equal to the random amount of access slots with duration of $\beta_{2}$, chosen uniformly from the range $[0 . . W-1]$, where the width of the competition window $W=W_{\text {base }} \cdot B L$, the base width of the competition window $W_{\text {base }}=16$ [2], the predicted channel load (back$\log ) B L=[1 . .64]$ adjusts the persistence level of channel nodes $p=1 / W$; 4) the transmission delay of the packet is equal to the duration of the transmission of $P L$ data bits over a channel with a bandwidth of $C$. The choice of equal number of access slots by nodes and simultaneous transmission leads to a collision that requires retransmission of data. The need to prevent collisions in the next packet cycle requires an increase of predicted load [2] on 1. A successful or free packet cycle is completed reducing by the nodes of predicted load on channel per unit to reduce access time.

Delivery services, types of addressing and types of messages transmitted have a significant impact on the transmission characteristics. Influence is connected with various change of parameters of a network [2, 3]: predicted loading (backlog, $b$ ), number of messages (message, $m$ ) in a network, number of active nodes-rivals (node, $n$ ) for the channel. Table 1 systematizes the parameters and the influence of the types of messages transmitted on the network parameters $(n, m, b)$ for successful and unsuccessful transmission. There are com-

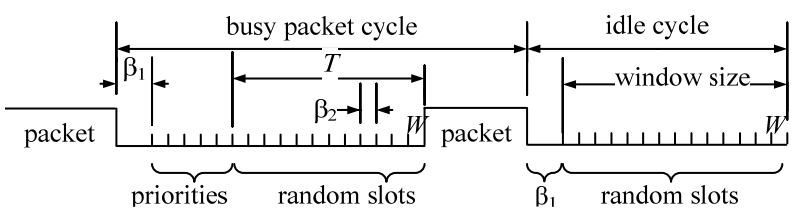

Figure 1 - The Structure of packet cycles 
e-ISSN 1607-3274 Радіоелектроніка, інформатика, управління. 2019. № 1 p-ISSN 2313-688X Radio Electronics, Computer Science, Control. 2019. № 1

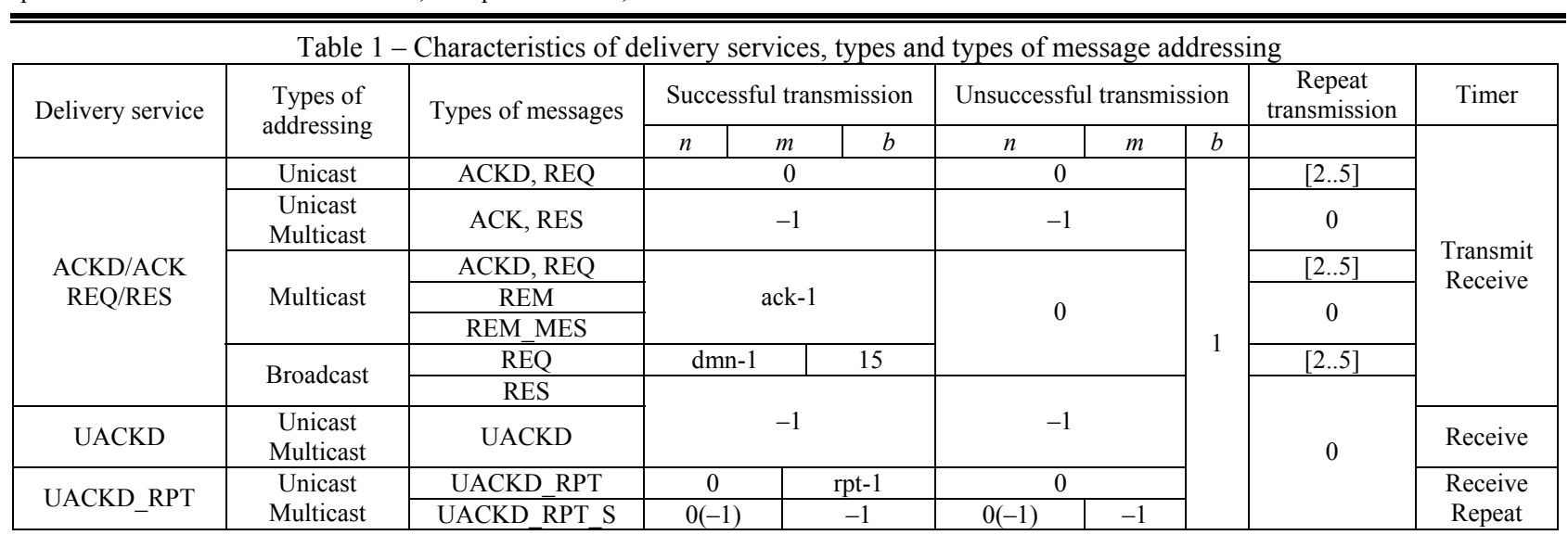

monly used the designation of services delivery [2]: service data transmission with acknowledgement (Acknowledged, ACKD/ACK, ACKD - message requiring the acknowledgement ACK); without acknowledgement (Unacknowledged, UACKD); without acknowledgement with the repetition (Unacknowledged_Repeated, UACKD_RPT, RPT - original message RPT_S - repeat message) reminder (Reminder/Message, REM - reminder REM_MES - reminder and message); the service request/response (Request/Response, REQ/RES, REQ is the request RES - response). Types of message addressing: unicast (unicast), multicast (multicast), broadcast (broadcast). For each type of message, individual counters are used: the counter of the maximum number of retransmissions (Retry count), the timer of the allowable transmission time (waiting for a response) (Transmit timer), the timer of receiving (recognition of duplicates) (Receive timer), and the minimum interval of the transmission delay of repeated messages (Repeat timer).

It is possible to present the work of the access and transfer protocol model in terms of Queuing systems. The service device in the model is a half-duplex network channel that processes information packets with a delay equal to the value of the packet cycle $\tau$. For ease of analysis it is advisable to take the initial restriction of the model for homogeneity of parameters of information load: the priorities, the size of information packets, types of addressing and services, the intensity $\lambda$ of the load nodes, etc. The information load generated by all nodes transmitting over the channel is the sum of the intensities $\lambda_{i}$ (packets per second) generated by each $i$-node separately:

$$
\lambda_{\Sigma}=\sum_{i=1}^{n} \lambda_{i}=n \cdot \lambda_{i} .
$$

The load of the transmission channel $\rho$ is determined by the relation of the load intensity $\lambda_{\Sigma}$ to the workflow intensity $\mu=1 / \tau$. Since the network uses services with retransmission of messages, the actual load of the channel may differ from the analytical one, which requires consideration in the model.

The analyzed service system is open (disconnected) that is, the nodes form packets regardless of the channel state, so that the probability of $i$-packets formation by nodes in the channel during any time interval $T$ is described by Poisson's distribution:

(C) Dadenkov S. A, 2019

DOI 10.15588/1607-3274-2019-1-18

$$
p_{i}=\frac{\left(\lambda_{\Sigma} \cdot T\right)^{i}}{i !} e^{-\lambda_{\Sigma} \cdot T} .
$$

For the time interval $T$, the size of the packet cycle $\tau$ should be taken, the average size of which can be determined based on the assumption that the network is in the saturation mode [18]. In view of the assumption of equality loads $\lambda$, created by each node separately, it is correct to assume the uniform distribution of messages of the system $m$ among all $n=N$ nodes of the channel. Thus, the amount of rival nodes $n$ per transmission channel changes proportionally to the amount of information messages $m$, i.e. $n=m$ for $n \leq m$, and $n=N$ for $m>n$.

The probabilistic process of generation and servicing of messages in the network can be represented using the discrete Markov chains. Model States should be characterized by the main selected parameters $(n, m, b)$, influencing the characteristics of access and transmission (Fig. $2)$. Different sets of parameters $(n, m, b)$ determine the sets of individual characteristics of each state of the model: the packet cycle time of transmission $\tau$, the probability of a successful $p_{\mathrm{y}}$ and unsuccessful $p_{\mathrm{\kappa}}$ transmission, the number $\mathrm{E}$ of transmission attempts before a successful, the delivery time $T_{\text {д }}$ of the message, the probability $p_{i}$ of the $i$ formation messages during the packet cycle. Assessment of these parameters of each state of the model is necessary for quantitative calculation of the model and can be performed according to the relations offered in [21]. Transitions between the States of the model should be associated with the probabilities of events: the probability of successful and unsuccessful transmission, the probability of formation of $i$ messages for a discrete time of the packet cycle. These probabilities form the joint events at discrete points in time of the model (the moments of completion of the packet cycles of the transmission) and definitely influence the change of the parameters of the state.

Correct drawing up of the state graph and transitions of the model requires considering the basic principles of message transmission. The transmission of a simple message without the possibility of re-sending and acknowledgment is characterized by the following provisions: the successful transmission ends with a reduction in the number of messages $m$ and rival nodes $n$ per channel by 1 
$(m \leq N)$; the collision (at $n \geq 2$ ) ends with the deletion of all messages $\geq 2(m-2)$ got in it. Changing the parameters of the model state also depends on the principle of collision detection: 1) nodes do not detect a collision; 2) nodes are guaranteed to detect a collision. The change of state parameters of model in successful transmission is invariant to the detection of collision: $(n \leq m, m-1+i, b-1)$ and is characterized by a decrease in the number of messages by 1 and an increase in the number of messages by $i$ generated by the network nodes during the access and transfer time $\tau$; a decrease in predicted load by 1 .

The result of changing the parameters in a collision when the nodes do not detect a collision is identical to the result of a successful transfer, but differs in that the number of messages per number of nodes $(\geq 2)$ in the model involved in the collision $(n \leq m, m-2+i, b-1)$ reduces. The variant with detection is differed by an increase in the predicted per channel load $(n \leq m, m-2+i), b+1)$. The influence of all possible outcomes of the packet cycle completion events on the parameters $(n, m, b)$ of the model state is presented in the form of an elementary graph in figure 2. The given mathematical description allows to construct a discrete Markov chain of the network model (Fig. 3). The state space of the model is divided into several parts, each of which is characterized by the following features: 1) the states of the model with the number of nodes-rivals for the channel $n<2$ are characterized by the lack of events of unsuccessful transmissions; 2) states with $n=m$ (at $m \leq N$ ) are characterized by the lack of message queues (one message per node); 3) states with $n=N$ (at $m$ $>N$ ) (Fig. 4, dotted line) are characterized by the existence of a message queue in the node (s), in which each node has one message and additionally each of $(m-N) \leq N$ nodes has at least one message in the transmission queue.

The discrete circuit meets the requirements of irreducibility and aperiodicity, and since all states of the model are returnable nonzero, there is a stationary probability distribution for it $[22,23]$. The quantitative calculation of stationary probabilities of States is possible provided that the chain has the property of finiteness. The predicted load and the number of messages per channel have Protocol limitations $B=64$ and $N=128$. The upper limit $M$ of the number of messages in the network channel can be set equal to the product of the number of nodes in the network and the capacity of the node message buffer, that is, $M=N \cdot q$. Thus, the dimension (number of states) $A$ of model:

$$
A=M \cdot B=N \cdot q \cdot B
$$

The calculation of stationary probabilities of the model can be performed by compiling and solving a system of linear algebraic equations [22, 23]. Further superposition of the model state parameters with the calculated stationary probabilities allows to determine the analyzed characteristics of the network channel: the probability of collision, successful delivery and loss of data, the distribution and the average values of access and transmission delay.

Modeling the various service delivery requires analysis of the transmission of different type messages (Table 2) and creation of model graphs peculiar to them. Previously, when modeling a service without acknowledgment (Fig. 2), in case of collision, the removal of two "encountered" messages from the system was accepted. However, the purpose of the analysis is to simulate a network with heterogeneity in delivery services. Thus, allowing heterogeneity of traffic and, accordingly, the possibility of participation in the collision of different type messages, it is necessary to revise the graph of the delivery service without acknowledgment. The most likely, taking into account the possible types of messages, is the loss of one message in the event of a collision (Fig. 4). This assumption

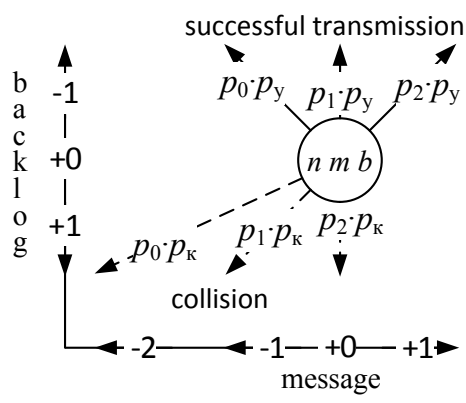

Figure 2 - Elementary model graph

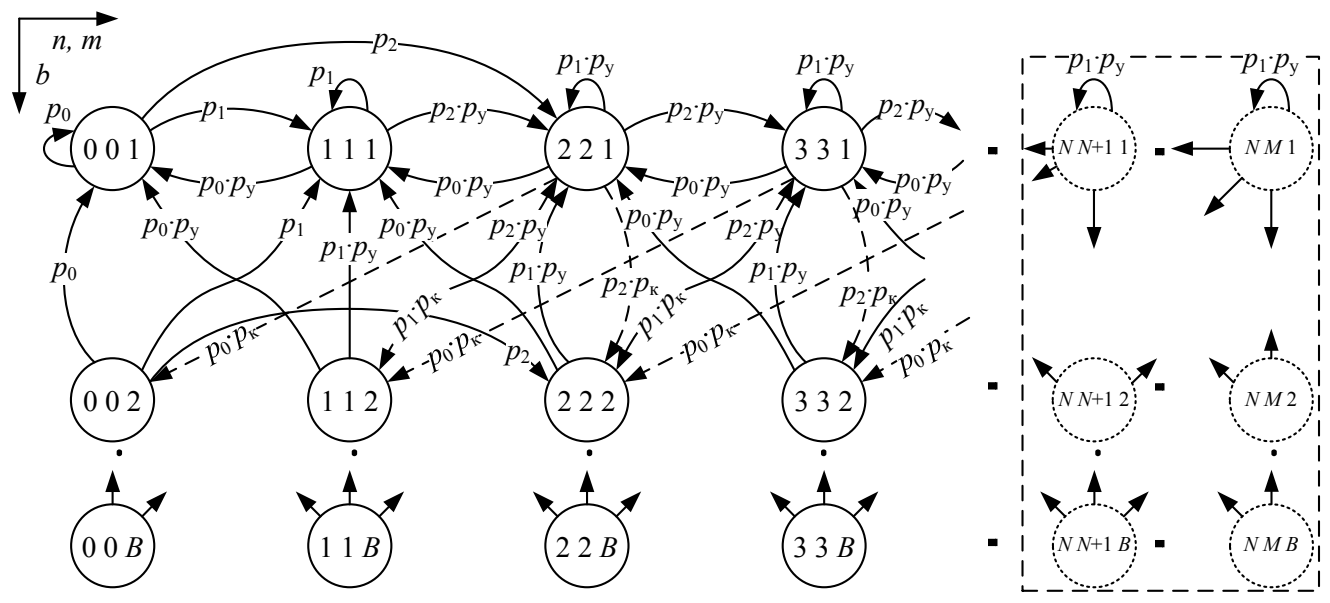

Figure 3 - Network channel model based on access protocol predictive p-persistent CSMA

(C) Dadenkov S. A, 2019

DOI 10.15588/1607-3274-2019-1-18 
successfull transmission

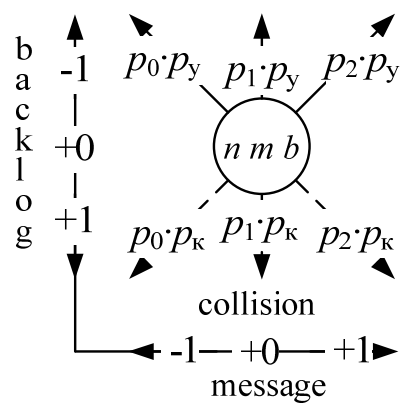

a

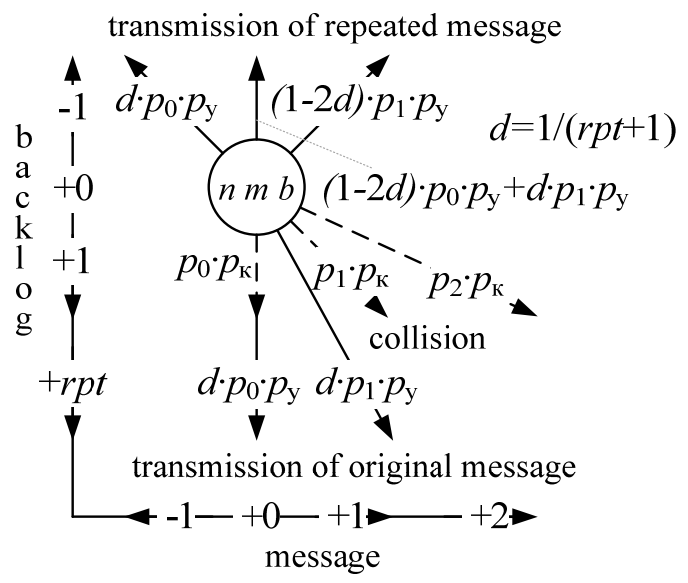

c transmission of acknowledgment

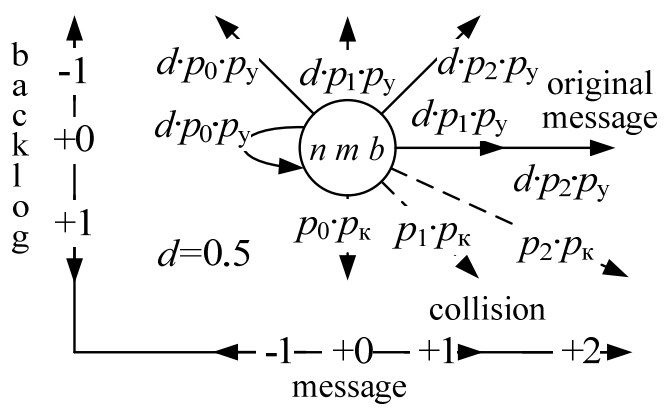

b

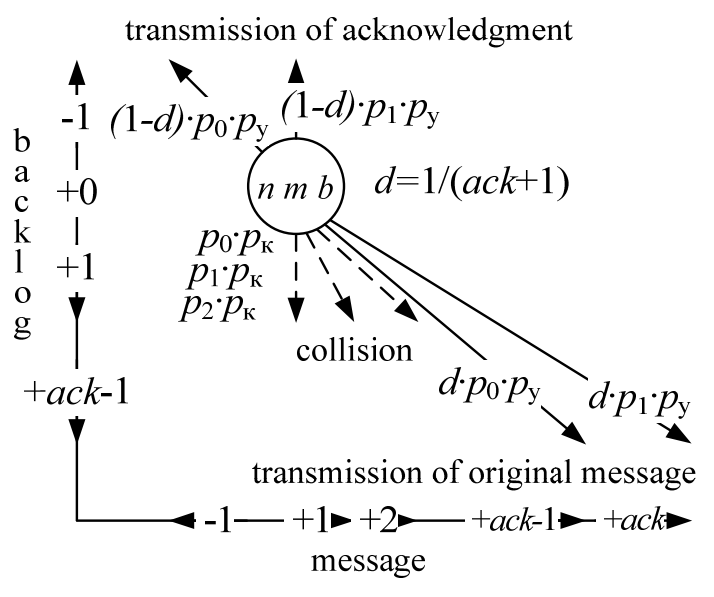

d

Figure 4 - The model graphs for different delivery and addressing services:

$\mathrm{a}$ - Service «without acknowledgment» Unicast/Multicast UACKD; b - Service «with acknowledgment», «response» Unicast ACKD/ACK, REQ/RES; c - Service «without acknowledgment, with repeat» Unicast/Multicast UACKD_RPT; d - Service «with acknowledgment», «response» Multicast ACKD/ACK, REQ/RES

will not significantly influence the small and medium load of the channel, and will be significant only with a large load, the analysis of which in practice is not of interest. Analysis of complex delivery services with more than one type of messages (as part of one delivery service) requires an analysis of the proportionality of their number within the model state with $\mathrm{m}$ messages. The proportionality for each service and type of addressing can be specified using the fraction $d$ of messages of various types in the model state (Fig. 4).

The proportion of messages of different services delivery:

1) Unicast transmission with acknowledgement or response (ACK/ACK, REQ/RES). For each original message there is a response, so the number of messages of types ACKD, REQ $(d=0.5)$ and acknowledgments (answers) ACK, RES $(d=0.5)$ is equal. The amount of messages in a collision does not change, that is, an unlimited number of retransmissions are accepted, which will influence only the simulation results with a large channel load;

2) Multicast transmission with confirmation (mACKD) or service request/response (REQ/RES). For each original message there are an ack of responses, for original messages $d=(1 /($ ack +1$))$, response $d=($ ack $/$

(C) Dadenkov S. A, 2019

DOI 10.15588/1607-3274-2019-1-18 $(a c k+1))$ (the estimated number of acknowledgements ack is equal to the number of nodes in the group grp-1);

3) Unicast/multicast without acknowledgements (UACKD). All messages are original, non-confirmed $(d=1)$

4) Unicast/multicast repeatable messages without acknowledgment (ACKS_RPT). To the original message is assumed $r p t$ of repeated messages, original message share $d=(1 /(r p t+1))$, repeated messages $d=(r p t /(r p t+1))$.

Thus, modeling of service by the channel of certain types of messages has to be performed by the made graphs (Fig. 4), considering in the state transition branches the coefficients $d$ at the probabilities of successful and unsuccessful message transmission. Created graphs allows to create a network model with different but homogeneous composition of services delivery of messages. Taking into account the heterogeneity of delivery services and types of addressing can be performed by superposition of the obtained elementary graphs of the model (Fig. 4) considering the share of their presence in the network traffic of the communication channel. A proportion $q_{k}$ of the traffic of a certain $k$-type of service delivery and addressing can be defined in the following way. As part of the total original intensity $\lambda_{\Sigma}$ of the message load on the network channel, it is necessary to identify individual 
components of the intensity $\lambda_{k}$ of each delivery service. So, the share of the intensity of the data traffic with the service $k$ can be defined by the relation:

$$
q_{k}=\frac{\lambda_{k}}{\lambda_{\Sigma}}
$$

Thus, the heterogeneity of delivery services and types of addressing in the model can be considered by the superposition of elementary graphs of delivery services (Fig. 4) taking into account the received traffic shares of various services as multipliers (probability of transmission in the packet cycle of the message of a certain service) at connections of elementary graphs.

The quantitative assessment of the model characteristics is based on the determination of stationary probabilities of the model states and the assessment of probabilistic-temporal characteristics of communication interactions of nodes in a distributed system by the obtained relations. Determination of stationary probabilities $\pi$ states of the Markov discrete chain model (Fig. 4) performed using the known methods $[22,23]$ of compiling and solving a system of linear algebraic equations on the matrix $\mathrm{P}$ of the probabilities of model transitions:

$$
\pi=\pi \cdot P=\left[\pi_{1}, \pi_{2}, \ldots, \pi_{A}\right] \cdot\left[\begin{array}{cccc}
p_{11} & p_{12} & \cdot & p_{1 A} \\
p_{21} & p_{22} & \cdot & p_{2 A} \\
\cdot & \cdot & \cdot & \cdot \\
p_{A 1} & p_{A 2} & \cdot & p_{A A}
\end{array}\right] .
$$

The result of solving the equation system is the determination of the vector $\pi$ of stationary probabilities of finding the system in each model state $(n, m, b)$. Assessment of probabilistic-time characteristics of the communication interactions of nodes in the network is performed using a covariant vector $\pi$ of the stationary probabilities of the states and contravariant vectors $U$ of the network characteristics in each model state [21]. Then the average values of $U$ characteristics can be determined by the general ratio:

$$
u=\sum(\pi \cdot U)
$$

By expression (6), it is necessary to assessment the average number of active nodes $n_{\mathrm{cp}}$ in the transmission channel, the average number of messages $m_{\mathrm{cp}}$ to be transmitted, the average duration of the packet cycle $\tau_{\mathrm{cp}}$ and the time of delivery of the message $T_{\text {д }}$ of the probability of collision $p_{\mathrm{K}}$ and successful transmission $p_{\mathrm{y}}$.

The message delivery time $T_{д}^{\mathrm{c}}$ must be calculated individually for each node, depending on the priority used in the delivery service transaction and the size of the sender and recipient node queues. This requires the correction of a calculation expression of the time of delivery $T_{\text {д }}$ of the message in the model state. The delivery time of a model-state message depends on the average queue size $r$ of the original node and is therefore equal to the product of the average delivery time $T_{\text {д }}$ and queue length:

$$
T_{\text {д }}^{\mathrm{c}}=T_{\text {д }} \cdot(1+r) .
$$

In the $(n, m, b)$ state of the model, the queues of all channel nodes contain $(m-n)$ messages. Given the equality of the intensities of the nodes, the messages in the queue, are uniformly distributed on the queues of the $n$ of nodes. Therefore, the average size of the node queue:

$$
r=\frac{(m-n)}{n} \text {. }
$$

Delivery time depends on the transmission service and the type of addressing. For the service "without acknowledgment" delivery time $T_{д}^{\mathrm{c}}$ is determined by the expression (7). This is true in the case of successful transmission, that is, with the probability of the reverse probability of the message loss $\left(1-p_{\pi}\right)$ (for the service "without acknowledgment" $p_{\text {п }}=p_{\text {к)}}$. For the service "with acknowledgment», the specified value $T_{\text {д }}$ of time is fair with the same probability $\left(1-p_{\Pi}\right)$. Thus, the probability of loss of message re-transmissions is lower for guaranteed detection of collisions. In case of lack of detection option, the node that sent the message during $t$, with a probability of unsuccessful delivery $p_{\text {ну }}=1-p_{\text {у }}$ is awaiting a response within the transmission timer. Therefore, the successful delivery of a message is preceded by the wait time for a certain number of retransmissions during the transmission timer. Then the average message delivery time:

$$
T_{\text {д }}^{\mathrm{c}}=\sum_{e=0}^{k}\left(T_{\text {д }}+e \cdot t\right) \cdot\left(1-p_{\text {ну }}\right) \cdot p_{\text {ну }}^{e},
$$

where $e$ is the number of successful transmission attempts, $k$ is the allowed number of retransmissions.

The full probability of losing the original message "with acknowledgment" during the transmitting through one or more channels of a distributed system is determined by the possible number of failed message deliveries:

$$
p_{\Pi}=p_{\text {ну }}^{k+1} \text {. }
$$

The message delivery time with the service "repeat transmission without acknowledgment" is determined by the time of a number of consecutive transmission attempts until successful, with a maximum number of transmission attempts equal to the number of repeated transmissions, provided that each transmission may fail with a collision. Then the expression for determining the delivery time (9) is also true for this service, regardless of the collision detection option, with the $t$ - timer of the repeated transmission (if the timer is less than the access time, then $t=T_{\text {д }}{ }^{\mathrm{c}}$ ). The probability of loss (unsuccessful delivery) of an information message is determined by expression (10).

When evaluating the average time of message delivery service "request/response" must be considered a sequence 
of message transmissions within a transaction. In this case, the delivery delay is composed of the time $T_{д i}$ and $T_{\text {діj }}$ of delivery of the original and response messages by the nodes $i, j$. The assessment should take into account the following: messages are generated and sent by nodes with different priority levels; the nodes that form the original and response message have different lengths $q$ of the transmission queue; the queue size of the responder node $q=0$, which is conditioned the priority of sending response messages; with the possibility of a collision $p_{\mathrm{K}}$, the message-response may be lost, the result is a retransmission of the original message after the transmission timer $t$ after it is sent. Considering presented, the delivery time can be determined by the expression (9), taking into account the fact that the delivery time of $T_{д}=T_{\text {ді }}+T_{\text {дj. }}$. However, the probability of unsuccessful delivery of message in a single transmission attempt in an expression depends on the ability of the node to detect a transmission collision. With the collision detection option, a message may not be delivered just because of a response message collision, and therefore the probability of an unsuccessful transmission $p_{\text {ну }}$ is equal to the probability of a collision. Without the collision detection option, the probability of an successful delivery is calculated as the probability of a collision in at least one transmission in the channel: $2 \cdot(1-$ $\left.p_{\mathrm{K}}\right) \cdot p_{\mathrm{\kappa}}+p_{\mathrm{K}}{ }^{2}$. The probability of losing a message with the service "request / response" should be calculated by the expression (10).

Calculation of delivery time of the message by nodes from different communication channels shall consider features of transfer through several intermediate channels. The case of collision detection is reviewed below. The complexity of the calculation is conditioned factors: the possibility of losing the message when transmitting not in one channel, but in several; the ability of communication nodes to perform retransmissions in case of a collision in each of the channels. Assume that the transit communication nodes of the network do not retransmit the message in case of a collision. Then the probability of unsuccessful message delivery in one attempt is equal to the sum of the probability of loss of messages in each folowing channel, provided that in all previous channels there was no loss:

$$
p_{\text {ну }}=\sum_{i=1}^{r} p_{\text {к } i} \cdot \prod_{o=1}^{i-1} \cdot\left(1-p_{\text {ко }}\right),
$$

where $r$ is the number of message transmission channels on the way from the source to the recipient. For the requestresponse service, the probability of unsuccessful delivery is determined based on the probability of non-delivery along the full transaction chain (to both "sides"). Taking into account the fact that the time of delivery $T_{\text {д }}$ in the distributed system represents the sum of the time of message delivery in each channel by different nodes, the delivery time can be calculated by the expression (9). The total probability of loss is described by the expression (10).

To solve the problem of quantitative assessment of the characteristics of the transfer protocol model, because of its inherent large dimension and high computational complexity, a software implementation of the construction and calculation of the characteristics of the analytical model in the system of engineering and scientific calculations MathCad were developed.

\section{EXPERIMENTS}

The main characteristics of data transmission $\left(\rho, T_{\text {д }}^{\mathrm{c}}\right.$, $\left.p_{\mathrm{y}}, p_{\mathrm{\kappa}}, p_{\text {пा }}\right)$ in the network with the protocol of random multiple access predictive $p$-persistent CSMA and heterogeneous delivery services are assessed for the four scenarios specified in table 2 were performed. The time parameters in the table are given in milliseconds, the intensity of transmission and processing of channels in the amount of packets processed per second, the channel bandwidth in kilobits per second, the message size in bits.

Table 2 - Initial data

\begin{tabular}{|c|c|c|c|c|c|c|c|c|c|}
\hline № & $N$ & $C$ & Pkt & $\lambda_{\Gamma}$ & $\boldsymbol{\mu}$ & $\boldsymbol{B}_{1}$ & $\boldsymbol{k}$ & $t$ & $d$ \\
\hline 1 & \multirow{4}{*}{20} & \multirow{4}{*}{78} & \multirow{4}{*}{96} & 25 & \multirow{4}{*}{293} & \multirow{4}{*}{$\begin{array}{c} \\
\beta_{1}= \\
=0.868 \\
\beta_{2}= \\
=0.168\end{array}$} & \multirow{4}{*}{3} & \multirow{4}{*}{20} & \multirow{4}{*}{$\begin{array}{c}d_{\mathrm{UACKD}}= \\
=0.4 \\
d_{\mathrm{ACKD}}= \\
=0.4 \\
d_{\mathrm{REQ}}=0.2\end{array}$} \\
\hline 2 & & & & 50 & & & & & \\
\hline 3 & & & & 100 & & & & & \\
\hline 4 & & & & 150 & & & & & \\
\hline
\end{tabular}

\section{RESULTS}

The results of the assessment of probabilistic and temporal characteristics of data transmission in the network with the protocol of random multiple access predictive $p$ persistent CSMA are shown in table 3.

\section{DISCUSSION}

Analysis of simulation results (Tab. 3) does not contradict the known provisions [3, 17-20] and allows making the following main conclusions:

- the linear increasing of the load on the communication channel (experiments 1-4) leads to an exponential increase in the loss probability and time of message delivery in the network;

- the increase in the difference in the time of message transmission with different delivery services occurs with the increase in the load of the communication channel and connected with the use of mechanisms for re-sending messages with a response due to the increase in the probability of collisions and the expiration of transmission timers;

- the equality of probabilities of message loss delivered to the services with acknowledgment and request/ response

Table 3 - Simulation results

\begin{tabular}{|c|c|c|c|c|c|c|c|c|}
\hline № & $\rho$ & $p_{\mathrm{y}}$ & $p_{\mathrm{K}}$ & $p_{\mathrm{II} \text { UACKD }}$ & $p_{\text {II ACKD\&REQ }}$ & $T_{д}^{\mathbf{c} \text { UACKD }}$ & $T_{\mathrm{A} \mathrm{ACKD} / \mathrm{ACK}}^{\mathrm{c}}$ & $T_{\mathrm{д}}^{\mathbf{c} \text { REQ/RES }}$ \\
\hline 1 & 0.16 & 0.9991 & 0.0009 & 0.0009 & $4.1 \cdot 10^{-6}$ & 4.14 & 4.14 & 8.28 \\
\hline 2 & 0.31 & 0.9960 & 0.0040 & 0.0040 & $1.9 \cdot 10^{-5}$ & 4.65 & 4.74 & 9.49 \\
\hline 3 & 0.57 & 0.9825 & 0.0175 & 0.0175 & $1.3 \cdot 10^{-4}$ & 6.24 & 6.61 & 13.75 \\
\hline 4 & 0.81 & 0.9457 & 0.0543 & 0.0543 & $1.0 \cdot 10^{-3}$ & 11.64 & 12.88 & 26.53 \\
\hline
\end{tabular}


is connected with the same number of retransmission attempts, sufficient to ensure a high probability of correct delivery in the transaction (the probability of loss of $p_{\mathrm{I}}=0.1 \%$ when loading $\rho=0.3$ ).

The proposed model and method of analysis allow performing a quantitative assessment of the main characteristics of data transmission in the network individually for each message delivery service, and depending on the main protocol characteristics of communication channels. This actualizes the use of the proposed analytical tools for the design of networks with the protocol of random multiple access predictive $p$-persistent CSMA and promotes to the problem solution of choosing the permissible composition of nodes in the communication channels and the message delivery services they use to provide the required performance characteristics and reliability of information transmission.

\section{CONCLUSIONS}

The analytical model is constructed and the method of quantitative estimation of probabilistic and time characteristics of information transmission in the network with the protocol of random multiple access predictive $p$ persistent CSMA widely used in distributed fieldbus networks of soft real time is offered. The scientific novelty of obtained results is that was the first to propose a model that takes into account the sporadic nature of heterogeneous types of messages network load nodes, with specific delivery services timers and transmission counters. The practical significance of the results is to improve the correctness of the assessment of the characteristics of the message transmission of different types and the possibility of using tools for the design of network channels with the choice of the permissible composition of nodes in the communication channels and used message delivery services to ensure the required performance characteristics and reliability of the transmission of sensory information. Prospects for further research are to create an algorithm for designing a sensor network with specified data transmission characteristics.

\section{ACKNOWLEDGEMENTS}

The research done with the financial support of RFBR in the framework of the scientific project №18-37-00070 "Algorithms for designing information and control networks LonWorks with the required probabilistic and temporal characteristics". The author expresses gratitude to the scientific supervisor prof. Kon Yefim Lvovich for the help and useful discussion of the work.

\section{REFERENCES}

1. Olifer V. G., Olifer N. A. Komp'yuternye seti. Printsipy, tekhnologii, protokoly: ucheb. dlya vuzov. 4-e izd., SPb., Piter, 2010, $944 \mathrm{p}$.

2. LonTalk protocol specification: ANSI/CEA-709.1-B. United States, 2006

3. Ditrix D., Shvajncer G. Yu. LON-texnologiya, postroenie raspredelennyx prilozhenij. Per. s nem. pod red. O. B. Nizamutdinova. Perm', Zvezda, 1999, 242 p.
4. Nazarov A. A., Kuznetsov D. YU. Issledovanie seti svyazi, upravlyaemoj adaptivnym protokolom sluchajnogo mnozhestvennogo dostupa, v usloviyakh kriticheskoj za-gruzki, Problemy peredachi informatsii, 2004, No. 3, pp. 69-80.

5. Nazarov A. A., TSoj S. A. Obshhij podkhod k issledovaniyu markovskikh modelej setej peredachi dannykh, upravlyaemykh staticheskimi protokolami sluchajnogo mnozhestvennogo dostupa, Avtomatika i vychislitel'naya tekhnika, 2004, No. 4 , pp. $73-85$.

6. Nazarov A. A., YUrevich N. M. Issledovanie seti so staticheskim h-nastojchivym protokolom sluchajnogo mnozhestvennogo dostupa «Alokha», Avtomatika $i$ vychislitel'naya tekhnika, 1995, No. 31, pp. 68-78.

7. KHomichkov I. I. Model' lokal'noj vychislitel'-noj seti s 1nastojchivym protokolom mnozhestvennogo dostupa, Matematicheskie metody issledovaniya setej svyazi i setej EHVM, 1990, No. 2, pp. 151-152.

8. KHomichkov, I.I. Model' lokal'noj seti s protokolom dostupa CSMA/CD, Avtomatika $i$ vychislitel'naya tekhnika, 1988, No. 5, pp. 53-58.

9. Stepanov S. N., TSitovich I.I. Otsenka veroyatnostnykh kharakteristik modelej s povtornymi vyzovami, Modeli raspredeleniya informatsii $i$ metody ikh analiza: $t r$. X Vsesoyuz. shk.-seminara po teorii teletrafika. Moscow, 1988, pp. 4-12.

10. Köhler, W. Simulation of a KNX network with EIBsec protocol extensions: building a KNX network with a simulation framework, 2010, $140 \mathrm{p}$.

11. Hong S. H., Kim W.H. Bandwidth allocation scheme in the CAN protocol, Control Theory and Applications: IEEE Proc., 2000, Vol. 147, pp. 37-44.

12. Hong, S.-H., Lee J.-H. A bandwidth allocation scheme in fieldbuses, International Journal of Control, Automation, and Systems, 2010, No. 8 (4), pp. 831-840. DOI: 10.1007/s12555-010-0415-1

13. Lian F.-L., Moyne J. R., Tilbury D. M. Performance evaluation of control networks: Ethernet, ControlNet, and DeviceNet. Technical Report: UM-MEAM-99-02, 1999. Peжим доступа: http://wwwpersonal.umich.edu/ tilbury/papers/lmt99csm.pdf (дата обращения: 28.09.2016).

14. Tindell K., Burns A., Wellings A. J. Calculating controller area network (CAN) message response times, Control Engineering Practice, 1995, Vol. 3, Issue 8, pp. 1163-1169. DOI: 10.1016/0967-0661(95)00112-8

15. Wen Li., Xiangyu Dai Performance Evaluation Analysis about Ethernet and DeviceNet, Internet of Things. Communications in Computer and Information Science, 2012, Vol 312, Springer, Berlin, Heidelberg, pp. 64-69. DOI: 10.1007/978-3-642-32427-7 9

16. Mary G. I., Alex Z. C., Jenkins L. Response Time Analysis of Messages in Controller Area Network: A Review, Journal of Computer Networks and Communications, 2013. DOI: 10.1155/2013/148015

17. Buchholz P., Plonnigs J. Analytical analysis of accessschemes of the CSMA type, Proc. of IEEE International Workshop on Factory Communication Systems WFCS, 2004, Wien, 2004, pp. 127-136.

18. Miśkowicz, M. Access delay in LonTalk MAC protocol, Computer Standards \& Interfaces. - Nederland: Elsevier Science Publishing Company, 2009, pp. 548-556. DOI: 10.1016/J.CSI.2008.03.025

19. Miśkowicz, M. Analysis of mean access delay in variablewindow CSMA, Sensors. Schweiz: Molecular Diversity Preservation International, 2007, Vol. 7, pp. 3535-3559. 
20. Moshe, K. Collision resolution simulation for distributed control architectures using LonWorks, IEEE International Conference on Automation Science and Engineering. Edmonton, 2005, pp. 319-326. DOI: 10.1109/COASE.2005.1506789

21. Dadenkov S. A. The simulation of p-persistent CSMA algorithm of unequal random multiple access. DOI: https://doi.org/10.15588/1607-3274-2018-2-11
22. Klejnrok, L. Vychislitel'nye sistemy s ocheredyami. Moscow, Mir, 1979, $600 \mathrm{p}$.

23. Krylov V. V., Samokhvalova S. S. Teoriya teletrafika i ee prilozheniya. $\mathrm{SPb}, \mathrm{BKHV}, 2005,288 \mathrm{p}$.

Received 01.11.2018. Accepted 09.12.2018

\section{УДК 004.057.4:004.051}

\section{АНАЛІТИЧНА МОДЕЛЬ ПРОТОКОЛУ СЛУЧАЙНОГО МНОЖИННОГО ДОСТУПУ РRЕDICTIVE Р- PERSISTENT CSMA}

Даденков С. А. - канд. техн. наук, доцент кафедри «Автоматика і телемеханіка» Пермського національного дослідженьнізації політехнічного університету, г. Пермь, Росія.

\section{АНОТАЦІЯ}

Актуальність. Створено нові моделі і спосіб кількісної оцінки імовірнісних і тимчасових характеристик інформаційнокеруючої мережі з протоколом випадкового множинного доступу з контролем несучої і прогнозуванням мережевого навантаження predictive p-persistent CSMA. Об'єктом дослідження був процес інформаційного обміну в fieldbus-мережах LonWorks, BacNet $з$ аналізованих протоколом.

Мета. Метою роботи є підвищення точності кількісних оцінок характеристик часу і надійності доставки інформаційних повідомлень в мережі з аналізованих протоколом.

Метод. Для вирішення завдання створення нової коректної моделі використаний апарат теорії ймовірностей. Виконано аналіз принципів функціонування протоколу predictive p-persistent CSMA і встановлені параметри впливають на його роботу (на прикладі стека LonTalk). Запропоновано граф станів і переходів моделі протоколу описує принципи передачі інформаційних повідомлень по мережі з розділяємим середовищем передачі, що враховує виділені значущі мережеві протокольні параметри. Запропоновано спосіб розрахунку графа і отримані нові аналітичні співвідношення для оцінювання основних імовірнісних і тимчасових характеристик моделі: середнього часу затримки передачі повідомлення, середній завантаженості каналу зв'язку, ймовірності успішної / невдалої передачі і втрати даних в мережі.

Результати. Розроблені модель і спосіб кількісної оцінки імовірнісних і тимчасових характеристик передачі даних в мережі з протоколом множинного доступу predictive p-persistent CSMA. Результати переважно відрізняются від аналогів коректним урахуванням спорадичною і різнорідної по сервісів доставки мережевого навантаження вузлів.

Висновки. Проведені експерименти підтвердили працездатність запропонованого математичного забезпечення і дозволяють рекомендувати його для вирішення завдань оцінки характеристик інформаційного обміну при проектуванні аналізіруемих мереж із заданими імовірнісними і тимчасовими характеристиками.

КЛЮЧОВІ СЛОВА: модель протоколу, випадковий множинний доступ, імовірнісні і тимчасові характерис-тики, передача інформації, промислова мережа, сенсорна мережа, LonWorks, fieldbus, predictive p-persistent CSMA.

УДК 004.057.4:004.051

\section{АНАЛИТИЧЕСКАЯ МОДЕЛЬ ПРОТОКОЛА СЛУЧАЙНОГО МНОЖЕСТВЕННОГО ДОСТУПА РRЕDICTIVЕ Р- PERSISTENT CSMA}

Даденков С. А. - канд. техн. наук, доцент кафедры «Автоматика и телемеханика» Пермского национального исследовательского политехнического университета, г. Пермь, Россия

\section{АННОТАЦИЯ}

Актуальность. Созданы новые модель и способ количественной оценки вероятностных и временных характеристик информационно-управляющей сети с протоколом случайного множественного доступа с контролем несущей и прогнозированием сетевой нагрузки predictive $p$-persistent CSMA. Объектом исследования являлся процесс информационного обмена в fieldbus-сетях LonWorks, BacNet с анализируемым протоколом.

Цель. Целью работы является повышение точности количественных оценок характеристик времени и надежности доставки информационных сообщений в сети с анализируемым протоколом.

Метод. Для решения задачи создания новой корректной модели использован аппарат теории вероятностей. Выполнен анализ принципов функционирования протокола predictive p-persistent CSMA и установлены параметры влияющие на его работу (на примере стека LonTalk). Предложен граф состояний и переходов модели протокола описывающий принципы передачи информационных сообщений по сети с разделяемой средой передачи, учитывающий выделенные значимые сетевые и протокольные параметры. Предложен способ расчета графа и получены новые аналитические соотношения для оценки основных вероятностных и временных характеристик модели: среднего времени задержки передачи сообщения, средней загруженности канала связи, вероятности успешной/неудачной передачи и потери данных в сети.

Результаты. Разработанные модель и способ количественной оценки вероятностных и временных характеристик передачи данных в сети с протоколом множественного доступа predictive $p$-persistent CSMA. Результаты преимущественно отличаются от аналогов корректным учетом спорадической и разнородной по сервисам доставки сетевой нагрузки узлов.

Выводы. Проведенные эксперименты подтвердили работоспособность предложенного математического обеспечения и позволяют рекомендовать его для решения задач оценки характеристик информационного обмена при проектировании анализируемых сетей с заданными вероятностными и временными характеристиками.

(C) Dadenkov S. A, 2019

DOI 10.15588/1607-3274-2019-1-18 
КЛЮЧЕВЫЕ СЛОВА: модель протокола, случайный множественный доступ, вероятностные и временные характеристики, передача информации, промышленная сеть, сенсорная сеть, LonWorks, fieldbus, predictive $p$-persistent CSMA.

\section{ЛІТЕРАТУРА/ЛИТЕРАТУРА}

1. Олифер В. Г. Компьютерные сети. Принципы, технологии, протоколы: учеб. для вузов / В. Г. Олифер, Н. А. Олифер. - 4-е изд. - СПб. : Питер, 2010. - 944 с.

2. LonTalk protocol specification: ANSI/CEA-709.1-B. United States, 2006.

3. Дитрих Д. LON-технология, построение распределенных приложений / Д. Дитрих, Д. Лой, Г. Ю. Швайнцер Пер. с нем. - под ред. О. Б. Низамутдинова. - Пермь : Звезда, $1999-242$ с.

4. Назаров А. А. Исследование сети связи, управляемой адаптивным протоколом случайного множественного доступа, в условиях критической загрузки / А. А. Назаров, Д. Ю. Кузнецов // Проблемы передачи информации. - 2004. - № 3. - С. 69-80.

5. Назаров А. А. Общий подход к исследованию марковских моделей сетей передачи данных, управляемых статическими протоколами случайного множественного доступа / А. А. Назаров, С. А. Цой // Автоматика и вычислительная техника. - 2004. - № 4. - С. 73-85.

6. Назаров А. А. Исследование сети со статическим hнастойчивым протоколом случайного множественного доступа «Алоха» / А. А. Назаров, Н. М. Юревич // Автоматика и вычислительная техника. - 1995. - № 31. С. $68-78$.

7. Хомичков И. И. Модель локальной вычислительной сети с 1-настойчивым протоколом множественного доступа / И. И. Хомичков // Математические методы исследования сетей связи и сетей ЭВМ. - 1990. - № 2. C. $151-152$.

8. Хомичков И. И. Модель локальной сети с протоколом доступа CSMA/CD / И. И. Хомичков // Автоматика и вычислительная техника. - 1988. - № 5. - С. 53-58.

9. Степанов С. Н. Оценка вероятностных характеристик моделей с повторными вызовами / С.Н. Степанов, И. И. Цитович // Модели распределения информации и методы их анализа: тр. X Всесоюз. шк. семинара по теории телетрафика. - М., 1988. - С. 4-12.

10. Köhler W. Simulation of a KNX network with EIBsec protocol extensions: building a KNX network with a simulation framework / W. Köhler. - 2010. -140 p.

11. Hong, S. H. Bandwidth allocation scheme in the CAN protocol / S. H. Hong, W. H. Kim // Control Theory and Applications: IEEE Proc. - 2000. - Vol. 147. - P. 37-44.

12. Hong S.-H. A bandwidth allocation scheme in fieldbuses / S.-H. Hong, J.-H. Lee // International Journal of Control,
Automation, and Systems. - 2010. - № 8 (4). - P. 831-840. DOI: $10.1007 / \mathrm{s} 12555-010-0415-1$

13. Lian F.-L. Performance evaluation of control networks: Ethernet, ControlNet, and DeviceNet. Technical Report: UM-MEAM-99-02 / F.-L. Lian, J. R. Moyne, D. M. Tilbury. - 1999. - Режим доступа: http://wwwpersonal.umich.edu/ tilbury/papers/lmt99csm.pdf (дата обращения: 28.09.2016).

14. Tindell K. Calculating controller area network (CAN) message response times / K. Tindell, A. Burns, A. J. Wellings // Control Engineering Practice. - 1995. - Vol. 3, Issue 8. P. 1163-1169. DOI: 10.1016/0967-0661(95)00112-8

15. Wen Li. Performance Evaluation Analysis about Ethernet and DeviceNet / Li Wen, Dai Xiangyu // Internet of Things. Communications in Computer and Information Science. 2012. - Vol 312. - Springer, Berlin, Heidelberg. - P. 64 69. DOI: 10.1007/978-3-642-32427-7 9

16. Mary G.I. Response Time Analysis of Messages in Controller Area Network: A Review / G. I. Mary, Z. C. Alex, L. Jenkins // Journal of Computer Networks and Communications, 2013. DOI: 10.1155/2013/148015

17. Buchholz P. Analytical analysis of access-schemes of the CSMA type / P. Buchholz, J. Plonnigs // Proc. of IEEE International Workshop on Factory Communication Systems WFCS. - 2004. - Wien, 2004. - P. 127-136.

18. Miśkowicz M. Access delay in LonTalk MAC protocol / M. Miśkowicz // Computer Standards \& Interfaces. - Nederland: Elsevier Science Publishing Company, 2009. P. 548-556. DOI: 10.1016/J.CSI.2008.03.025

19. Miśkowicz M. Analysis of mean access delay in variablewindow CSMA / M. Miśkowicz // Sensors. Schweiz: Molecular Diversity Preservation International. - 2007. Vol. 7. - P. 3535-3559.

20. Moshe K. Collision resolution simulation for distributed control architectures using LonWorks / K. Moshe // IEEE International Conference on Automation Science and Engineering. - Edmonton, 2005. - P. 319-326. DOI: 10.1109/COASE.2005.1506789

21. Dadenkov S. A. The simulation of p-persistent CSMA algorithm of unequal random multiple access. DOI: https://doi.org/10.15588/1607-3274-2018-2-11

22. Клейнрок Л. Вычислительные системы с очередями / Л. Клейнрок. - М. : Мир, 1979. - 600 с.

23. Крылов В. В. Теория телетрафика и ее приложения / В. В. Крылов, С. С. Самохвалова. - СПб. : БХВ, 2005. $288 \mathrm{c}$. 